\title{
Perbedaan metode pembuatan VCO antibakteria terhadap sifat Fisikokimia, dan uji organoleptik, Antibakteri VCO terhadap Bakteri Staphylococcus Aureus
}

\author{
Octo Zulkarnain ${ }^{*}$, Suci Ferdiana ${ }^{2}$ \\ ${ }^{1,2}$ Prodi S1 Ilmu Keperawatan Sekolah Tinggi Ilmu Kesehatan Surabaya, Indonesia \\ *octo.zulkarnain@stikessurabaya.ac.id
}

\begin{abstract}
Wounds have slowed healing due to the formation of biofilms, which are the surface formation of bacterial cells that are covered by the polymeric substance. Staphylococcus aureus is a gram-positive bacteria that play a role in producing multilayer in biofilms and is very easy to resistant to antibiotics. VCO has the ability as an anti-bacterial content based on lauric acid and kaprat acid. This study used experimental Quasy with a mixed Methode method. VCO is made with 3 methods, fishing, heating and mixing on physicochemical test. Physicochemical test results show, the highest water content is found in the VCO heating, the same three-type weight, the highest peroxide number is in the VCO mixing and the highest free fatty acids on the VCO fishing. The results of antibacterial test with Kirby-Baur method There is no barrier zone from the 3 types of VCO. VCO used as a topical is VCO fishing.
\end{abstract}

The results of a test analysis of the results of observations in patients as much as 15 people for 9 days in 3 treatments with chronic wounds obtained $p<0.05(0.000)$ which means during the treatment that the wound condition is better.

Keyword: Organoleptic, Staphylococcus aureus, Physicochemical, VCO

\section{PENDAHULUAN}

Jenis bakteri yang berevolusi menjadi MRSA adalah Staphylococcus Aureus. Bakteri ini banyak ditemukan di lingkungan sekitar kita dan banyak berperan dalam kejadian infeksi salah satunya infeksi terhadap pada luka kronis yang mengakibatkan munculnya biofilm.

Staphylococcus aureus adalah merupakan bakteri gram positif yang banyak menyebabkan infeksi kulit, dan mukosa pada manusia. Staphylococcus aureus diperkirakan $15 \%$ dari populasi orang dewasa terpapar terus menerus, hampir $80 \%$ kolonisasi bakteri tersebut di dapatkan pada tenaga kesehatan (Tracey A.2017). Salah satu penyebab luka sulit untuk sembuh adalah terbentuknya biofilm. Biofilm merupakan bentukan permukaan sel bakteri yang dilingkupi oleh ekstarselluler polymeric substance (EPS) (Homenta H. 2016). Salah satu bakteri yang berperan dalam proses terbentuknya biofilm adalah staphylococcus aureus. Bakteri ini berperan dalam menghasilkan multilayer dalam biofilm dan sangat mudah resisten terhadap antibiotic (Archer, N.K. 
et.al.2011). Pengobatan terhadap infeksi banyak mengandalkan antibiotik sebagai solusinya. Penggunaan antibiotik yang irrasional dapat memicu terjadinya resistensi terhadap antibiotik itu sendiri. Selain itu dampak antibiotik berdampak buruk untuk perkembangan flora normal usus dan pembentukan vitamin $\mathrm{B}$ dan $\mathrm{K}$ (Anna,L.K. 2009). Karena banyaknya permasalah akibat dampak penggunaan antibiotik inilah peneliti berkeinginan mengembangkan fitofarmaka dengan menggunakan buah kelapa sebagai bahan utamanya. Buah kelapa akan diubah menjadi VCO (Virgin Coconut Oil) dengan 3 cara yaitu pemanasan, mixing dan pancingan. Hasil VCO dijadikan bahan topikal atau salep luka kronis dan melihat efek penggunaan VCO terhadap penyembuhan Luka. Kemampuan VCO sebagai anti bakteri didasarkan kandungan asam laurat dan asam kaprat (6- $7 \%)$. Pemberian VCO topikal 0,4 cc / hari mampu membunuh bakteri sehingga dapat mengurangi jumlah bakteri pada luka secara bermakna(8). Karena ketertarikan tersebut peneliti menyusun proposal penelitian dan mengajukannya dalam skim Penelitian Dosen Pemula (PDP) dari Kemeterian RISTEK DIKTI tahun usulan 2018 untuk pendanaan tahun 2019-2019.

\section{METODE PENELITIAN}

Dalam penelitian peneliti menggunakan bahan kelapa sebagai bahan utama dalam membuat VCO. Kelapa yang digunakan adalah kelapa bali dengan karakteristik daging kelapa tebal dan menghasilkan banyak santan. Tiga metode yang diterapkan dalam membuat VCO. VCO pertama adalah dengan metode pancingan, kedua adalah dengan metode pemanasan dan yang ketiga dengan metode mixing. Ketiga metode tersebut murni hanya menggunakan bahan VCO tanpa campuran bahan lainnya. Ketiga hasil VCO kemudian dilakukan uji fisikokimia untuk melihat unsur kandungan kadar air, berat jenis, bilangan peroksida dan kandungan asam lemak bebas. Pengujian selanjutnya adalah metode untuk melihat perbedaan warna, rasa dan endapan pada ketiga jenis VCO dengan organoleptic dengan panelis yang tak terlatih. Selanjutnya adalah uji anti bakteria dengan metode Kirby-baur disk diffusion. Langkah selanjutnya adalah melakukan intervensi pada luka kronis pada pasien dengan DM.

Jenis penelitian ini adalah eksperimental dengan metode mixing method. Metode yang menggambungkan antara data kuantitatif dengan kulitatif (Foodrisc Reource center. 2016). Data uji fisikokimia akan dijabarkan dalam bentuk kuantitatif (berupa angka), data organoleptic dibahas dalam bentuk 
kuantitatif, hasil uji hambat dijabarkan dalam bentuk kualitatif dan uji pengaruh topical terhadap luka kronis dijabarkan dalam bentuk kuantitatif.

\section{HASIL DAN PEMBAHASAN}

Hasil uji fisikokimia pada VCO dengan metode pembuatan yang berbeda adalah sebagai berikut :

Tabel 1. Hasil uji fisikokimia VCO dengan tiga metode pembuatan yang berbeda.

\begin{tabular}{lll}
\hline Pancing & Pemanasan & Mixing \\
\hline Kadar Air & Kadar Air & Kadar Air \\
$0.5 \%$ & $1.4 \%$ & $0.94 \%$ \\
\hline Berat Jenis & Berat jenis & Berat jenis \\
0.92 & 0.9218 & 0.9215 \\
\hline Bilangan & Bilangan & Bilangan \\
peroksida 0.41 & peroksida 0.19 & peroksida \\
mgrek $\mathrm{O}_{2} / \mathrm{Kg}$ & mgrek $\mathrm{O}_{2} / \mathrm{Kg}$ & 1.01 mgrek \\
& & $\mathrm{O}_{2} / \mathrm{Kg}$ \\
\hline Asam lemak & Asam lemak & Asam lemak \\
bebas 2.4\% & bebas 2.26\% & bebas 2.36\% \\
\hline
\end{tabular}

Dari penjabaran tabel 1 diatas dapat dijelaskan bahwa kandungan kadar air tertinggi dimiliki oleh VCO dari hasil pemenasan $1.4 \%$ untuk berat jenisnya ketiganya tidak menunjukkan perbedaan yang signifikan, namun yang tertinggi adalah VCO pemanasan. Bilangan peroksida tertinggi VCO hasil mixing. Kandungan asam lemak tertinggi ada pada VCO hasil pancingan.

Hasil uji organoleptic yang bertujuan untuk melihat perbedaan warna, aroma , rasa dan endapan didapatkan hasil sebagai berikut.

Perbedaan warna yang signifikan antara tiga sampel A VCO pancingan sampel VCO pemanasan sampel VCO mixing $(\mathrm{p}=0.000<\alpha=0,05)$. Perbedaan aroma yang signifikan antara ketiga sampel $(\mathrm{p}=0.000<\alpha=0,05)$. Perbedaan rasa yang signifikan antara 3 sampel $(p=0.000<\alpha=$ 0,05). Endapan tidak menunjukkan perbedaan antara 3 sampel dengan hasil $(\mathrm{p}=0.90>\alpha=0,05)$.

Uji zona hambat pertumbuhan staphylococcus aureus dengan menggunakan metode Kirby-baur disk diffusion. Sebuah metode yang sering digunakan untuk menguji untuk menguji daya hambat sebuah antibiotic terhadap bakteri pathogent tertentu ${ }^{17}$. Sampel terdiri atas 5 sampel, satu sampel control positif, 1 sampel control negative dan 3 sampel untuk jenis VCO dengan metode yang berbeda. Jenis bakteri yang digunakan pada uji ini adalah staphylococcus aureus Hasil yang di dapakan dari hasil uji Kirby-baur disk diffusion control positif menunjukkan memilki zona hambat, control negative tidak terjadi zona hambat dan ketiga jenis varian VCO menunjukkan hasil 0 (nol) yang artinya tidak memilki zona hambat.

Tabel 2. Hasil uji zona hambat terhadap bakteri staphylococcus aureus.

\begin{tabular}{ll}
\hline Perlakuan & Rata-rata penghambatan bakteri \\
& staphylococcus aureus
\end{tabular}




\begin{tabular}{lll}
\hline & $\begin{array}{l}\text { Diameter zona } \\
\text { hambat }(\mathrm{mm})\end{array}$ & $\begin{array}{l}\text { Pengahambatan } \\
\text { rat-rata }(\%)\end{array}$ \\
\hline $\mathrm{P}(-)$ & 0.00 & 0 \\
\hline $\mathrm{P}(+)$ & $24,5 \pm 61$ & 37,5 \\
\hline $\mathrm{P} 0$ & 0.00 & 0 \\
\hline $\mathrm{P} 1$ & 0.00 & 0 \\
\hline $\mathrm{P} 2$ & 0.00 & 0
\end{tabular}

$\mathrm{P}(-)=$ Aquades steril, $\mathrm{P}(+)$ antibiotic klorampenikol, $\mathrm{P} 0=\mathrm{VCO}$ pancingan, $\mathrm{P} 1=$ VCO pemanasan, $\mathrm{P} 2=\mathrm{VCO}$ mixing.

Hasil uji antibakteria dengan melihat zona hambat bakteri menujukkan bahwa dari lima sampel yang digunakan hanya sampel kontrol possitif yang menunjukkan adanya zona hambat pada uji tersebut.

Hasil uji topical VCO pancingan terhadap luka kronis adalah sebagai berikut : hasil analisis data menggunakan uji ANOVA yang dilakukan selama 3 kali dalam waktu 9 hari didapatkan hasil nilai signifikansi 0.000, yang artinya selama perawatan yang dilakukan kondisi luka semakin lebih baik. Rincian hasil penghitungan anilisis menggunakan anova juga diadapatkan data bahwa perawatan hari ke-3 menunjukkan hasil paling signifikan menunjukkan $\mathrm{p}<0.05 \quad(0.001)$ yang artinya hasil pada perawatan ke-3 yang terbaik dibandingkan hari ke-2 dan ke-3.

Berdasarkan hasil uji fisikokimia yang telah dilakukan peneliti kadar air tertinggi dimiliki oleh VCO pemanasan sebesar $1,4 \%$. Campuran air yang tinggi dimungkinkan akibat dari bercampurnya air pada saat pembuatan dan tidak bisa dipisahkan dengan metode biasa. Kadar air yang tinggi dapat memicu reaksi kimia seperti rekasi redoks dan enzimatik sehingga dalam waktu yang cepat VCO akan berbau tengik (3).

Kadar berat jenis berdasarkan hasil uji fisikokimia menujukkan tidak ada perbedaan yang berarti dari ketiganya. Kandungan peroksida tertinggi terdapat pada VCO mixing dengan kandungan 1.01 mgrek $\mathrm{O}_{2} / \mathrm{kg}$. kandungan peroksida yang tinggi akibat reaksi oksidasi yang mengakibatkan munculnya radikal bebas. Proses pengadukan yang dilakukan menggunakan alat mixer memungkinkan terjadi reaksi oksidasi (Asy'ari M. dan Cahyo B. 2006). Kandungan asam lemak bebas dari hasil uji fisikokimia menunjukkan asam lemak tertinggi terjadi pada VCO pancingan meskipun tidak terlalu spesifik perbedaan ketiganya. VCO pancing mengikuti kandungan VCO yang digunakan sebagai bahan pancingan. Hasil VCO pancingan akan identik dengan bahan yang digunakan untuk Pancingan.

Hasil uji organoleptic menunjukkan ada perbedaan yang siginifkan antara, warna, aroma , rasa. Sedangkan endapannya tidak menujukkan perbedaan yang signifikan. Karena melalui metode yang berbeda maka hasil VCO dari ketiganya akan menggambarkan perbedaan 
antara warna, aroma dan rasa. Sedangkan endapan tidak menunjukkan perbedaan yang spesifik karena proses penyaringannya dilakukan dengan Teknik dan jumlah penyaringan yang sama.

Hasil uji zona hambat bakteri Staphylococcus Aureus menujukkan gambaran dari ketiga sampel VCO yang diujikan secara invitro zona hambat 0 (nol) sedangkan uji zona hambat pada kontrol positif menujukkan gambaran zona hambat, dan kontrol negative juga tidak menunjukkan zona hambat. Sifat antibakteria dalam VCO berasal monogliserida dan asam lemak bebas yang keduanya berasal dari senyawa trigliserida. Trigliserida dapat aktif dan berubah menjadi monogliserida dan asam lemak bebas jika berada dalam tubuh manusia. Penggunaan topikal VCO dapat mengaktifkan trigliserida yang dimiliki VCO untuk menjadi anti bakteria (Widiyanti R,A. 2015).

Hasil pengujian luka dengan menggunakan topical VCO pancing ternyata memberikan dampak yang signifikan terhadap proses penyembuhan luka. Gambaran luka di awal pertemuan tanpa terlihat jelas biofilm sehingga proses penyembuhannya terhambat. Kondisi yang lembab pada permukaan luka dapat meningkatkan proses perkembangan perbaikan luka, mencegah dehidrasi jaringan dan kematian sel (Ismail D.D.S.L, et.al 2009). Hasil pengujian secara invitro VCO yang dihasilkan tidak memberikan daya hambat pada bakteri staphylococcus aureus namun VCO merupakan bahan minyak yang dapat mendukung kelembapan luka.

\section{SIMPULAN DAN SARAN Simpulan}

VCO memberikan pengaruh terhadap proses penyembuhan luka pada 15 pasien dengan luka kronis, meskipun pada gambaran analisis uji hambat yang dilakukan secara invitro tidak menujukkan reaksi hambatan terhadap bakteri staphylococcus aureus. Hasil uji fisikokimia juga menggambarkan bahwa VCO denga pancingan, pemanasan, dan mixing tidak memenuhi standart VCO yang berkualitas. Hasil VCO dengan metode yang berbeda tidak memberikan karakter hasil warna, aroma, endapan dan rasa yang berbeda.

\section{Saran}

VCO dapat membantu dalam proses penyembuhan karena sifatnya berupa minyak sehingga dapat membuat luka menjadi moist/ lembab. Dan VCO yang dihasilkan tidak memenuhi standar untuk dikonsumsi namun telah terbukti memberikan dampak terhadap proses penyembuhan luka.

\section{DAFTAR PUSTAKA}


Anna,L.K. 2009. Dampak Penggunaan Antibiotik yang Irasional, lifestyle.kompas. cited at 1 november 2019 . https://lifestyle.kompas.com/read/2 009/09/17/11223219/dampak.peng gunaan.antibiotik.yang.irasional?p $\underline{\text { age }=\text { all } /}$

Archer,

N.K.\&

Mazaitis,M.J.,Shirtliff,M.E. 2011. staphylococcus aureus biofilmvrulence.2(5):445-459.

Asy'ari M. dan Cahyo B. 2006. Prastandarisasi: Produksi dan Analysis Minyak Virgin Coconut Oil (VCO). Researchgate, 9(3). cited at 1 november 2019. https://www.researchgate.net/publi cation/273755055_Pra

Standarisasi_Produksi_dan_Analis is_Minyak_Virgin_Coconut_Oil_ VCO.

Foodrisc Reource center. 2016. Mixed Methods Research. Cited at 18 oktober 2019. http://resourcecentre.foodrisc.org/ mixed-methods-research_185.html

Homenta H. 2016. Infeksi Biofilm Bacterial. Jurnal e-Biomedik (eBm), 4(1),1-5.reteive from https://ejournal.unsrat.ac.id/index.p hp/ebiomedik/article/view/11736/1 1329.
Hudzicki Jan. 2009. Kirby-Bauer Disk Diffusion Susceptibility Test Protocol. American Society For Microbiology.

https://www.google.com/url?sa=t\& source=web\&rct=j\&url=https://w ww.asm.org/getattachment/2594ce 26-bd44-47f6-8287-

0657aa9185ad/Kirby-Bauer-DiskDiffusion-Susceptibility-TestProtocolpdf.pdf\&ved=2ahUKEwjfiPXO19 DlAhU5yosBHVRrBNoQFjAheg QIBRAB\&usg=AOvVaw30HVIHI oxXNMitPAj5oyxm.

Ismail D.D.S.L, Irawati Dewi \& Haryati T.S. 2009. Modern dressing improve the healing process in diabetic wound penggunaan balutan modern memperbaiki proses penyembuhan luka diabetic. Jurnal Kedokteran Brawijaya, 15(1), halaman, 32-35.

Susanto, Sujatno \& yuwono. Efek Antibakteri Virgin Coconut Oil Terhadap Methicillin Resistant Staphylococcus Aureus. Medicinus Vol. 4 No. 8. Februari 2015 - Mei 2015.

Tracey A. Taylor1; Chandrashekhar G. Unakal. 2017. Staphylococcus Aureus StatPearls Publishing LLC. https://www.ncbi.nlm.nih.gov/boo ks/NBK441868/.29/9/2018. 
Widiyanti R,A. 2015. Pemanfaatan kelapa menjadi VCO (Virgin Coconut Oil) sebagai antibiotik kesehatan dalam upaya mendukung visi indonesia sehat 2015. Prosiding Seminar Nasional Pendidikan Biologi 2015, yang diselenggarakan oleh Prodi Pendidikan Biologi FKIP Universitas Muhammadiyah Malang. reteive from http://biology.umm.ac.id/files/file/ $577-$

584\%20Rahma\%20Ayu\%20Widiy anti.pdf 